\title{
AL-ṢULH!̣: DALAM ARBRITASE TATA HUKUM ISLAM KLASIK
}

\author{
Agus Salim \\ Pasca Sarjana Institut Agama Islam Negeri Purwokerto, Indonesia \\ E-mail: agussalimsulaseh@gmail.com
}

\begin{abstract}
This paper discusses arbitration in the classical Islamic legal system. The emergence of Islamic financial institutions today not only affect the financial system with shariah lebel only, more than that, the emergence of shariah financial institutions also affect some legal provisions on the settlement of disputes arising from transactions made Islamic financial institutions with their customers. In this paper the authors use the risert library method with the noramatif approach of Islamic law. In classical Islamic law the settlement of non-litigation disputes can be entered through the Shari way, in the process al-Ṣulh para parties may choose to use al-Hakam (referee) or self-negotiate. The peace process by raising al-Hakam in our legal terms is very similar to the process of Arbitration, therefore it is interesting to take the theme of Arbitrage in the classical Islamic law.
\end{abstract}

Keywords: al-Ṣulḥ, Taḥkîm, Hạam, Badan Arbitrase Syariah

\section{Pendahuluan}

Perkembangan lembaga keuangan syariah di Indonesia diakui tidak hanya mempengaruhi sistem ekonomi, melainkan juga mempengaruhi sistem hukum yang berlaku di Indonesia, khususnya hukum yang mengatur tentang ekonomi dan penyelesaian sengketa. Lahirnya Undangundang Nomor 7 tahun 1992 tentang perbankkan, dan diubah menjadi Undang-undang Nomor 10 tahun 1998 yang secara implisit menyebutkan bank yang berdasar pada prinsip syariah, serta lahirnya Undang-undang Nomor 21 tahun 2008 tentang perbankkan syariah, dan Undang-undang Nomor 19 Tahun 2008 tentang surat berharga syariah Negara. Dari beberapa undang-undang ini mempengaruhi perkembangan hukum dalam penyelesaian sengketa ekonomi syariah. Lahirnya undangundang Nomor 3 tahun 2006 Tentang pengadilan agama, sebagai perubahan Undang-undang Nomor 7 Tahun 1989 tentang pengadilan agama, di mana pengadilan agama diberi kewenangan untuk 
menyelesaikan sengketa ekonomi syariah. Begitu juga peraturan Mahkama Agung Nomor 2 tahun 2008 tentang Kompilasi Hukum Ekonomi Syariah adalah bukti dari pengaruh perkembangan sistem ekonomi Islam dalam tata hukum di Indonesia.

Lahirnya Kompilasi Hukum Ekonomi Syariah (KHES) sebagai hukum yang menjadi pedoman hakim pengadilan agama adalah jawaban untuk mengisi kekosongan hukum. Sebelum lahirnya Kompilasi Hukum Ekonomi Syariah, penyelesaian sengketa ekonomi Islam mengandalkan pada berbagai keputusan dari Dewan Syariah Nasional Majlis Ulama Indonesia (DSN-MUI) dan Badan Arbitase Syariah Nasioanal (Basyarnas), yang (dimana penyelesaian sengketa) dilakukan di luar pengadilan. ${ }^{1}$ Penyelesaian sengketa dengan cara persidangan bersifat menyelesaikan hukumnya dan tetapi tidak dalam konstruksi untuk menyelesaikan masalah secara social dan kekekeluargaan. ${ }^{2}$

Pola penyelesaian masalah secara hukum juga menghasilkan pihak yang menang di satu sisi dan pihak yang kalah di sisi lainnya. ${ }^{3}$ Hal ini merupakan konsekuensi logis dalam penyelesaian sengketa dipengadilan. Masalah ini menjadi kekhawatiran masyarakat dan fakar ekonomi Islam yang merasa perlu mendapat perhatian bersama. Untuk mengantisipasi kekhawatiran tersebut, maka Majelis Ulama Indonesia (MUI) telah memprakasai dibentuknya Badan Arbitrase Muamalat Indonesia (BAMUI) yang diresmikan pada tanggal 21 Oktober 1993 di Jakarta. ${ }^{4}$ Badan Arbitrase Muamalat Indonesia dianggap tidak sesuai dengan undang-undang Nomor 16 Tahun 2001 tentang yayasan, kemudian Dewan Sayariah Nasioanal Majlis Ulama Indonesia pada tanggal 24 Desember 2003 memutuskan penggantian nama badan arbitrase dari Badan Arbitrase Muamalat Indonesia menjadi Badan Arbitrase Syariah Nasional. ${ }^{5}$

\footnotetext{
1 Ridwan, Hukum Ekonomi Syariah di Indonesia, (Purwokerto: STAIN Purwokerto Press, 2016), 04.

2 Maskur Hidayat. Strategi dan Taktik. Mediasi, Berdasarkan Perma No.1 Tabun 2016 tentang Prosedur Mediasi Di Pengadilan. (Jakarta: Kencana, 2016), V.

${ }^{3}$ Maskur Hidayat. Strategi dan Taktik. Mediasi.., V.

${ }^{4}$ Tri Setiadi, "Arbitase Islam dalam Presfektif Islam Dan Hukum Positif” Fiat Justisia Jurnal Hukum, Volume 9 No. 3 Juli- September 2015, 342.

5 Perubahan Badan ArbitraseMuamalah Indonesia menjadi Badan Arbitrase Syariah Nasional memerlukan proses yang sangat lama. Rencana perubahan itu berawal dara usulan pembahasan tentang perubahan badan Arbitraseoleh dewan syariah nasional majelis ulama Indonesia setahun sebelumnya yakni tanggal 23-26 desember 2002. Hal ini sebagaimana dijelaskan oleh Syahrizal Abbas dalam memaparkan penjelasan Yudoparipurno, dalam buku Syahrizal Abbas, Mediasi dalam Hukum Syariah, Hukum Adat, dan Hukum Nasional. (Jakarta: Kencana Prenada Media Grup, 2011), 358.
} 
Penyelesaian sengketa perdata dilihat dari lembaga penyelesaianya mengenal dua bentuk penyelesaian, yaitu penyelesaian di luar pengadilan (non-litigasi) dan penyelesaian di pengadilan (litigasi). Bambang Sutioso ${ }^{6}$ mengatakan bahwa, pada umumnya mekanisme penyelesaian melalui jalur non litigasi dianggap sebagai primium remendium/first resort (upaya awal) dalam menyelesaikan sengketa. Sedang jalur litigasi baru digunakan manakala upaya penyelesaian secara kekeluargaan atau perdamaian tidak berhasil dilakukan oleh para parties.

Di Indonesia penyelesaian sengketa di luar pengadilan dilakukan melalui perdamaian. Hal itu diatur dalam pasal 1851 kitab undangundang hukum perdata, yang berbunyi: "Suatu perjanjian dengan mana kedua belah pibak, dengan menyerabkan, menjanjikan atau menaban suatu barang, mengakbiri suatu sengketa yang sedang bergantung ataupun mencegah timbulnya suatu sengketa", 7 Pasal 1851 ini diperjelas dengan pasal 1 ayat 10 Undangundang Republik Indonesia Nomor 30 Tahun 1999, tentang arbitase dan alternatif penyelesaian sengketa, yang menyatakan; alternatif penyelesaian sengketa adalah lembaga penyelesaian sengketa atau bada pendapat melaui prosedur yang disepakati para pihak yakni penyelesaian di luar pengadilan dengan cara konsultasi, negosiasi, mediasi, konsiliasi atau penilaian ahli.

Dalam undang-undang Nomor 4 tahun 2004 tentang kekuasaan kehakiman, keberadaan arbitrase dapat dilihat dalam penjelasan Pasal 3 ayat (1) yang menyebutkan bahwa: "ketentuan ini tidak menutup kemungkinan penyelesaian sengketa di luar pengadilan Negara melalui perdamaian atau arbitrase", dengan demikian, penyelesaian sengketa di luar pengadilan atas perdamaian atau melalui arbitrasetetap diperbolehkan, akan tetapi keputusan Arbiter hanya mempunyai kekuatan eksekutorial setelah memperoleh eqsekuatur atau perintah untuk menjalankan dari pengadilan. ${ }^{8}$

Arbitrase adalah salah satu bagian dari penyelesaian sengketa alternatif yang dilakukan oleh parties ${ }^{9}$ yang bersengketa di luar pengadilan dengan menunjuk wasit atau Arbiter. Undang-undang Republik Indonseia Nomor. 30 tahun 1999, tentang arbitrase dan alternatif penyelesaian sengketa, pasal 1 ayat (1) mengatakan, arbitrase adalah cara penyelesaian suatu sengketa di luar pengadilan umum yang didasarkan pada perjanjian

\footnotetext{
${ }_{6}$ Bambang Sutioso, Hukum Arbitase dan Penyelesaian Sengketa, (Yogyakarta: Gema Media, 2008), 06.

${ }^{7}$ Oyo Sunaryo Muklhas, Perkembangan Peradilan Islam dari Kabin di Jazirah Arab Keperadilan Agama di Indonesia, (Bogor: Ghalia Indonesia, 2011), 16.

8 Oyo Sunaryo Muklhas, Perkembangan..., 16. Dan Bamabang Sutioso, Hukum Arbitase, 108.

${ }_{9}$ Pihak-pihak yang bersengketa dalam suatu sengketa yang mereka sengketakan
} 
arbitrase yang dibuat secara tertulis oleh para pihak yang bersengketa. ${ }^{10}$ Parties yang memilih arbitrase sebagai suatu penyelesaian sengketa, berarti mereka mempunyai keinginan untuk keluar dari penyelesaian sengketa di depan pengadilan, sehingga dalam penyelesaian sengketa melalui arbitrase, parties sebelumnya telah membuat kesepakatan (klausul) bahwa penyelesaian sengketa yang terjadi pada perjanjian mereka harus diselesaikan di luar pengadilan. Pater B. Rutledge ${ }^{11}$ mengatakan:

Arbitration, one would think, essentially involves private conduct. In arbitration parties contractually exit the system of state controlled dispute resolution in favor of a purely private system wherein they authorize a private decision maker to resolve their right and obligation. Proceending typically are convidential, end the parties agree in advance to be bound by the result reached by the decision maker.

Pada umumnya parties yang memilih arbitrase sebagai penyelesaian sengkata melalui arbitrase telah membuat perjanjian atau klausul berisi tentang, jika terjadi persengketaan antara kedua belah pihak dikemudian hari, penyelesaian sengketa akan diselesaikan melalui artbitrase, namun boleh juga parties yang tidak membuat klausul perjanjian tersebut memilih menyelesaikan sengketanya dengan melalui jalur arbitrase. Muhammad Basyarah ${ }^{12}$ dalam bukunya mengatakan, sebetulnya dengan memilih APS (Alternatif Penyelesaian Sengketa) pihak yang bersengketa seharusnya mengacu pada kontraknya sendiri (jika ada), yaitu pada klausul kontrak yang menunujukan kepada penggunaan pihak ketiga untuk membantu jika negoisasi tidak berhasil.

Adanya klausul perjanjian yang dibuat oleh para parties dapat kita simpulkan adanya subyek hukum yang melakukan perjanjian dan obyek yang dijanjikan oleh parties. Dalam hal ini, subyek hukum yang melakukan perjanjian dan yang membuat klausul adalah para parties, sedang obyek yang dijanjikan adalah suatu masalah yang timbul dikemudian hari. Sudiarto dan Zaini Asyhadie $^{13}$ dalam bukunya mengatakan ada tiga subyek hukum yang dapat melakukan perjanjian arbitrase, yakin (a) Orang-perorangan (natural person), (b) Badan-badan

10 Undang-undang Republik Indonesia Nomor 30 tahun 1999, Tentang Arbitrasedan Alternatif Penyelesaian sengketa.

${ }_{11}$ Pater B. Rutledge, Arbitration and The Constutional. (New York: Cambridge University Press, 2014), 01

12 Mochamad Basarah. Prosedur Alternatif Penyelesaian Sengketa ArbitraseTradisional dan Modern (Online), (Yogyakarta: Genta Publising, 2011), 2.

13 Sudiarto dan Zaini Asyhadie. Mengenal Arbitase Salah Satu Alternatif Penyelesaian Sengketa Bisnis, (Jakarta: PT. Raja Grafindo Persada, 2004), 65. 
hukum dan (c) lembaga atau organisasi peremerintah dan Negara (state). Obyek perjanjian yang dapat disengketakan melalui jalan arbitrase telah disebutkan dalam pasal 5 ayat 1 Undang-undang Nomor 30 Tahun 1999, yakin meliputi sengketa perdagangan dan hak yang menurut hukum dan peraturan undang-undangan dikuasai sepenuhnya oleh pihak yang bersengketa.

Klausul yang dibuat dalam perjajian para parties menjadi salah satu pertimbangan Arbiter dalam menyelesaikan sengketa para parties. Arbiter ${ }^{14}$ dalam penyelesaian arbitrase bertugas untuk mendamaikan para pihak yang bersengketa. Ia (arbiter) bisa tunggal dan bisa pula majelis. Dalam arbitrase syariah ada ketentuan khusus selain Arbiter harus ahli dalam masalah sengketa yang diajukan padanya.

Abdul Manan menjelaskan, Bahwa syarat utama menjadi Arbiter tunggal atau Arbiter majelis di antaranya, beragama Islam yang taat menjalankan agamanya dan tidak terkena larangan berdasarkan peraturan perundang-undangan yang berlaku. Dalam menjalankan tugasnya Arbiter harus mengupayakan perdamaian semaksimal mungkin, dan apabila usaha ini berhasil, maka Arbiter membuat akta perdamaian dan menghukum kedua belah pihak untuk mentaati dan memenuhi perdamaian tersebut. Jika perdamaian tidak berhasil, maka Arbiter akan meneruskan pemeriksaannya, dengan cara para pihak membuktikan dalildalil gugatannya, mengajukan saksi-saksi atau mendengar para ahli, dan sebelum mengajukan keterangannya, ia harus disumpah terdahulu. ${ }^{15}$

Lebih lanjut, penyelesaian sengketa dengan cara arbitrase bersifat tertutup, dan asas ini tidak bersifat mutlak atau permanen. Akan tetapi dapat dikesampingkan jika atas persetujuan kedua belah pihak setuju sidang dilaksanakan terbuka untuk umum. Kepentingan pemeriksaan secara tertutup ini adalah menghindari publisitas demi menjaga nama baik perusahaan atau bisnis masing-masing para pihak. Putusan BAMUI (Basyarnas) bersifat final dan mengikat bagi para pihak yang bersengketa dan (para pihak) wajib mentaati putusan tersebut, para pihak harus mentaati dan memenuhi pelaksanaanya. Apabila ada para pihak yang tidak melaksanakan itu secara sukarela, maka putusan itu dijalankan menurut ketentuan yang diatur dalam Pasal 637 dan 639 Rv. Yakni pengadilan negeri memiliki peranan sangat penting dalam memberikan

\footnotetext{
${ }^{14}$ Orang yang disepakati oleh dua bela pihak yang besengketa untuk memberikan keputusan yang akan ditaati oleh kedua bela pihak. Dalam istilah ilmu Fikih juga di istilahkan sebagai muhakam atau orang yang disepakati oleh dua bela pihak untuk menyelesaikan perkaranya. 15 Abdul Manan, Hukum Ekonomi Syariah dalam Presfektif Kewenangan Peradilan Agama, Jakarta: Kencana Perdana Media Group, 2014), Cet. II, 464-465.
} 
exequartur bagi putusan Arbiter. ${ }^{16}$ Dan juga melalui undang-undang Nomor 3 Tahun 2006 Tentang pengadilan agama, pengadilan agama memiliki peranan penting dalam peenyelesaian sengketa ekonomi syariah.

Penyelesaian sengketa dengan cara arbitrase diminati oleh banyak parties yang bersengketa dalam sengketa bisnis dan ekonomi dibanding mereka menyelesaikan sengketanya di pengadilan. Selain lebih tertutup dari publisitas, penyelesaian sengeketa dengan cara arbitrase juga dianggap lebih ekonomis, lebih cepat dan memiliki nilai-nilai yang tidak menimbulkan permusuhan dikemudian hari.

\section{Perdamaian dalam Tata Hukum Islam Klasik}

Pada masa awal kehadiran Islam, Nabi Muhammad bin Abdullah tampil sebagai qâdı̂ (hakim) menggantikan posisi ḥakam bahkan mengambil alih jabatan kâhin (penasihat kerohanian). Dalam perkembangan berikutnya jabatan qâḍ̂ itu mulai dilembagakan, dan menempati posisi penting sebagai sarana untuk menyelesaikan sengketa yang terjadi di masyarakat. ${ }^{17}$

Nabi Muhammad memutus sengketa-sengketa pidana dan perdata yang dihadapkan pada beliau. Dalam sebuah Hadist yang diriwayatkan oleh Jabir, sesungguhnya ayah Jabir meninggal dalam peperangan Uhud, dan ayah Jabir memiliki hutang. Suatu hari beberapa orang yang memberi hutang datang kepada Jabir, kemudian Jabir meminta kepada mereka yang memberi hutang pada ayahnya agar mereka menerima buah yang ada di kebun sebagai ganti hutang ayahnya, namun mereka tidak mau menerima, dan pada saat itu Jabir mendatangi Rasulullah, kemudian buah itu diberikan oleh Rasulullah pada mereka yang memberi hutang ayah Jabir. ${ }^{18}$

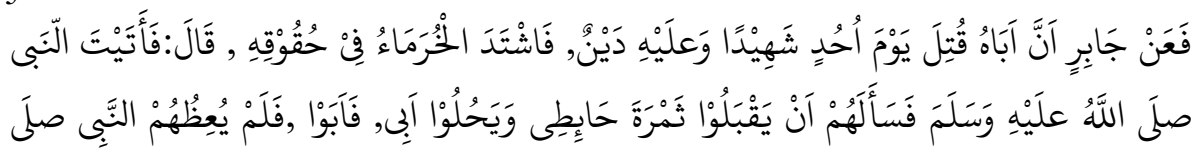

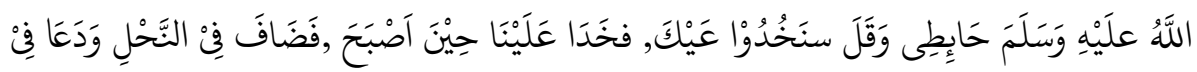

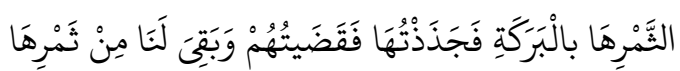

Dari riwayat ini dapat kita ketahui bahwa, pada masa Nabi Muhammad penyelesaian sengketa pada awal mulanya tidaklah melalui lembaga pengadilan, hal ini dikarenakan posisi Nabi adalah seorang

\footnotetext{
16 Abdul Manan, Hukum Ekonomi, 465.

17 Abdul Manan, Hukum Ekonomi, 465; dan Oyo Sunaryo Mukhlas, Perkembangan Peradilan Islam, xvi.

18 Sayyid Sâbiq. Fiqh al-Sunnah, (Sudan: al-Maktabah al-Asyariyah, 2011), Vol. 3, 220.
} 
khalifah yang mengurus Negara, mengurus agama dan juga beliau berkedudukan sebagai sumber hukum dan pemberi keputusan bagi siapa saja yang terpidana atau bagi mereka yang bersengketa perdata.

Nabi dikenal sebagai hakam dalam al-sulh tidak hanya pada saat Nabi telah menjadi seorang Nabi dan Rasul, melainkan juga Nabi dikenal sebagai hakam sebelum beliau di utus sebagai Nabi. Pemindahan hajar aswad oleh orang arab yang kemudian menyebabkan konflik antara mereka, saat itu pula Nabi tampil sebagai hakam yang mendamaikan kedua kelompok yang bertikai. ${ }^{19}$

Demikian perhatian yang sangat besar dalam menegakkan keadilan dicurahkan oleh Umar Bin Khaththab. Kepedulian Umar Bin Khaththab dalam rana pengadilan tercermin dari dictum risâlat al-qadâ' sebagai prinsip penyelenggaraan pengadilan yang dirumuskan dalam mengangkat hakim. Umar Bin Khaththab tidak segan-segan melakukan uji kemampuan. Di antaranya dilakukan pada Syureih Ibnu Harist yang ditunjuknya sebagai pemutus suatu sengketa yang melibatkan Umar Bin Khaththab selaku tergugat. Dalam putusan yang diambil Syureih Ibnu Harist itu, ternyata dianggap sangat teliti, bijak, cepat, dan tepat sehingga mendapat empati dan pujian dari Umar Bin Khaththab. Dengan nada puas Umar Bin Khaththab berkata: "Ini adalah suatu putusan yang benar", Karena itu pula, kemudian Umar Bin Khaththab Mengangkat Syuraih Ibn Harist menjadi hakim Kufah. ${ }^{20}$ Dalam perkembangannya, pengangkatan hakim kemudian dilanjutkan oleh khalifah-khalifah setelahnya.

Di dalam hukum Islam sebagaimana kita temui dalam kitab-kitab fikih klasik, dikenal ada dua cara penyelesaian sengketa. Dua cara penyelesaian sengketa tersebut adalah; pertama, al-sulh, al-sulb ${ }^{21}$ diartikan oleh ulama ahli fikih sebagai sebuah akad yang diperuntukan untuk menyelesaikan persengketaan di antara dua orang yang bersengketa. Kedua, al-qad̂a, alqadâ menurut bahasa artinya menghukumi sesuatu dan memutuskannya. Sedang al-qadâ menurut istilah adalah penegakan hukum di antara masyarakat. ${ }^{22}$ Menurut sebagian Ahli hukum yang lain, sebagaimana diungkapkan oleh Muhammad Hasbi Ash Shidieqy, ${ }^{23}$ al-qaḍa adalah

\footnotetext{
19 Ahwan Fanani, "Resolusi Konflik Alternatif dalam Hukum Islam" Al-Manabij, Vol.VII, No. 2, Juli 2013, 281.

20 Oyo Sunaryo Mukhlas, Perkembangan, xvi-xvi.

21 Sayyid Sâbiq, Fiqh al-Sunnah, 218.

22 Sihabbudin Abi Abas, Anwâr al-Masâlik, (Surabaya: Maktabah Hidayah, t.th.), 268.

23 Muhammad Hasbi Ash Shiddieqy, Peradilan Dan Hukum Acara Islam (Semarang:. PT. Pusataka Rizki Putra, 1997), Cet. I, 34.
} 
lembaga hukum atau perkataan yang harus dituruti yang diucapkan oleh seseorang yang mempunyai wilayah umum, atau menerangkan hukum agama atas dasar mengharuskan orang mengikutinya. Dari dua cara penyelesaian tersebut yang hampir sama dengan arbitrase adalah al-sulh, di mana kesamaannya ada pada penyelesaian sengketa di luar lembaga pengadilan atau disebut juga penyelesaian sengketa non-litigasi. Penyelesaian sengketa dengancara ini, para parties tidak lagi membutuhkan hakim dalam al-qad̂a melainkan membutuhkan seorang arbiter atau wasit.

Al-sulh adalah akad penyelesaian sengketa bagi dua orang yang bersengketa. ${ }^{24}$ Al-sulh disebutkan oleh Al-Qur'an maupun dalam Hadist secara jelas. Al-Qur'an surat an Nisa' ayat 128 menyebutkan "Dan jika seorang wanita khawatir akan nusyuz atau sikap tidak acub dari suaminya, maka tidak mengapa bagi keduanya mengadakan perdamaian yang sebenar-benarnya dan perdamaian itu lebih baik (bagi mereka), walau manusia itu tabiaatnya kikir..", dan Hadist Nabi:

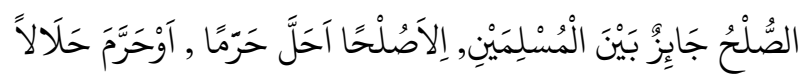

Artinya: "Perdamaian adalah hal yang diperkenankan di antara dua orang muslim, kecuali perdamaian atas sesuatu yang halal menjadi haram dan perdamaian atas sesuatu yang haram menjadi halal." (HR. Turmudzi, No. 1352)

Dari dua nass ini dapat disimpulkan bahwa penyelesaian sengketa dengan cara al-sulh pada prinsip penyelesaiannya adalah perdamaian yang dilakukan oleh dua belah pihak yang besengketa. Secara implisit prinsip perdamaian dalam penyelesaian sengketa melalui al-sulh tersebut sesuai dengan pandapat ulama Malikiyah ${ }^{25}$ yang membagi bentuk putusan al-sulh. dalam tiga bagian yakni, (a) Putusan menggugurkan kewajiban parties yang didakwa, (b) Putusan membebaskan parties yang didakawa dan (c) memerintahkan parties yang didakwa untuk mengganti sesuatu dakwaan yang didakwakan.

Syarat al-sulh Menurut Wahbah Zuhaily ${ }^{26}$ adalah sesuatu yang berkaitan dengan al-sulh itu sendiri, yakni sighat atau kesepakatan perjanjian, orang yang menginginkan berdamai, orang yang diajak berdamai dan barang yang diperdamaikan. Dari penjelasan Wahbah Zuhaily ini tidak disyaratkan adanya wasit dalam penyelesaian sengketa

\footnotetext{
${ }^{24}$ Sayyid Sâbiq, Fiqh al-Sunnah, 218.

${ }_{25}$ Wahbah Zuhaily, Fiqh al-Islami wa Adilatuh, (Bairut: Darul Fikr, 2014), Cet. 34, Vol. V, 186.

${ }^{26}$ Wahbah Zuhaily, Fiqh al-Islâmi, 189.
} 
melalui al-sulh. Penjelasan Wahba mempertegas para parties dapat berdamai dengan cara negosiasi antara keduanya tanpa menggunakan arbiter atau wasit.

Dalam tata hukum Islam klasik sebagaimana disebutkan, dilihat dari syarat dan akad al-sulh tidak disyaratkan adanya penengah atau wasit dalam penyelesaiannya, namun tidak menutup kemungkinan para parties mengangkat wasit atau penengah dalam penyelesaian sengketanya. Hal ini sesuai yang dilakukan Nabi saat memutus sengketa Ayah Jabir, dan sesuai yang dilakukan oleh Syuraih pada perkara Umar bin Khatob yang dibahas pada pembahasan sebelumnya.

Konsep al-sulh pada dasarnya diperkenankan dalam segala obyek yang disengketakan, kecuali perdamaian atas sesutu yang halal menjadi haram, dan yang haram menjadi halal. ${ }^{27}$ Namun pada gilirannya para ulama berselisih pendapat tentang hal ini. Syayid Sabiq dalam bukunya menjelaskan bahwa syarat obyek sengketa yang disengketakan dalam penyelesaian dengan cara al-sulh adalah sesuatu yang tidak keluar dari sengketa-sengketa tertentu, pertama, sesuatu yang disengketakan harus berupa harta benda yang memiliki nilai harga atau manfaat, dan kedua, sengketa yang disengketakan adalah sesuatu yang menjadi hak seorang hamba (haqq al-adamî) yang diperbolehkan untuk disengketakan menurut hukum syariah, hal ini walau sengketa yang disengketan bukan harta benda melainkan hak qisâs (hak pidana). Adapun hak hamba pada Allah tidaklah dapat didamaikan, dengan demikian akad al-sulh yang berkaitan dengan perbuatan zina, minum khamr, qisâs tidak dapat didamaikan menggunakan harta benda sebagai gantinya. Jika hakim dalam kaitan ini menerima harta benda sebagai pengganti hukuman zina, minum khamr dan qișas, maka hakim (tersebut) termasuk orang yang menerima suap. ${ }^{28}$

\section{Arbitrase dalam Tata Hukum Islam Klasik}

Sebagaimana disebutkan sebelumnya, bahwa penyelesaian sengketa dalam hukum Islam klasik secara garis besar hanya mengenal dua cara penyelesaian sengketa, yakni pertama, dengan cara proses pengadilan (alqadâ) dan kedua, dengan cara perdamaian (al-sulb). Proses penyelesaian sengketa melalui perdamian (al-sulh) pun juga memiliki dua macam penyelesaian, yakni; (a) penyelesaian dengan perdamaian di luar pengadilan tanpa menggunakan wasit, dalam hal ini para parties langsung

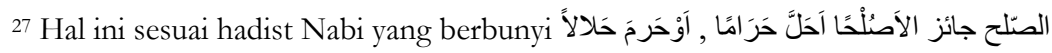

${ }^{28}$ Sayyid Sâbiq, Fiqh al-Sunnah, 220-221.
} 
berhadap-hadapan menyelesaikan sengketanya, ${ }^{29}$ dan (b) proses penyelesaian di luar pengadilan dengan menunjuk wasit dalam penyelesaian sengketanya.

Menurut ahli hukum, dewasa ini arbitrase disejajarkan dengan konsep tahkim. Al-sulh merupakan payung besar bagi berbagaai ragam resolusi konflik dalam hukum Islam, sepatutnya tạ̣kim masuk dalam kerangka alsulh tersebut. ${ }^{31}$ Mardani sebagaiman dikutip oleh Muhammad Arifin mengatakan, arbitase dalam study hukum Islam dikenal dengan sebutan tạkeim, secara literal, tahkîm berarti mengangkat (seorang) sebagai wasit atau juru damai. ${ }^{32}$ Menurut Muhammad Hasbi Ash Shiddieqy, tạ̣kim dalam pengertian bahasa arab ialah menyerahkan putusan pada seseorang dan (orang menyerahkan sengketanya pada orang lain yang dipercayainya) menerima putusan itu. tabkeim di dalam pengertian istilah ialah, dua orang atau lebih men-taḅkim-kan kepada seorang atau lebih, yang kepada mereka untuk diselesaikan sengketa dan ditetapkan hukum syara' atas sengketa mereka itu. ${ }^{33}$

Al-sulh (perdamaian) dengan cara taḅkim tidaklah sama dengan penyelesaian sengketa di dalam pengadilan, walau sama-sama ada pihak ketiga sebagai pemutus. Abdul Aziz Dahlan sebagaimana dikutip Muhammad Arifin mengatakan, perbedaan antara pengadilan dengan arbitrase tersebut selaras dengan kedudukan antara hakim pada qad̂a (pengadilan) dengan ḅakam pada tạ̣kim (arbitrase), perbedaan tersebut sebagaimana berikut; pertama, hakim harus memeriksa dan meneliti secara seksama sengketa yang diajukan kepadanya dan dilengkapi dengan bukti, sedangkan hakam tidak harus demikian. Kedua, wilayah dan wewenang

\footnotetext{
29 Dalam Qur'an Surat Annisa Ayat 128 “Dan jïka seorang wanita khawatir akan nusyu₹, atau sikap tidak acub dari suaminya, maka tidak mengapa bagi keduanya mengadakan perdamaian yang sebenar-benarnya dan perdamaian itu lebih baik (bagi mereka) walau manusia itu tabiaatnya kikir..." dalam ayat ini tidak menyebutkan adanya wasit dalam proses perdamaian, sementara dalam surat anisa ayat 35 secara jelas menyatakan adanya wasit yang dipilih oleh para parties dalam penyelesaian sengketanya. Surat Annisa ayat. 35 menyatakan "maka angkatlah seorang bakam dari keluarga si laki-laki dan seorang hakam dari keluarga si wanita, jika keduanya menghendaki perbaikan (perdamaian), niscaya Allah akan member taufik kepada keduanya.

${ }^{30} \mathrm{Hal}$ ini sesuai dengan perdamaian yang ditawarkan oleh Qur'an suart An Nisa 35, yang artinya: Dan jika kamu kbawatirkan ada persengketaan anatara keduanya, maka kirimkanlah seorang bakam dari keluarga laki-laki dan seorang hakam dari keluarga perempuan. Jika kedua hakam itu bermaksud mengadakan perbaikan, niscaya Allah memberitaufik kepada suami istri itu. Sesunggubnya Allah Maha mengetahui lagi maha mengenal.

31 Ahwan Fanani, 280.

32 Muhammad Arifin, Arbitrase Syariah Sebagai Piliban Forum Penyelesaian Sengketa Perbangkan Syariah, (Yogyakarta: Pustaka Pelajar, 2016), Cet. I, 229.

33 Muhammad Hasbi Ash Shiddieqy, Peradilan dan Hukum Acara Islam, 81-82.
} 
ḩakam ditentukan oleh akad pengangkatnya dan tidak tergantung pada kerelaan dan persetujuan pihak-pihak yang diadili, sedangkan hakim mempunyai wewenang yang terbatas pada kerelaan dan persetujuan pihak-pihak yang mengangkat dirinya sebagai hakim. Ketiga, tergugat harus dihadirkan di hadapan hakim, sedang dalam tabkim masing-masing pihak tidak dapat memaksa lawan sengketanya untuk hadir pada majelis taḅkim, kedatangan masing-masing pihak tersebut berdasarkan kemauan sendiri. Keempat, putusan hakim mengikat, dan dapat dipaksakan pada kedua belah pihak yang bersengketa, sedang putusan bakam akan dilaksanakan berdasarkan kerelaan masing-masing pihak yang bersengketa. Dan kelima, di dalam tahkim ada beberapa masalah yang tidak boleh diselesaikan, sedangkan di dalam pengadilan negera semua persoalan dapat diperiksa dan diselesaikan. ${ }^{34}$

Selain perbedaan tersebut di atas, seorang hakim dalam qad̂a adalah diangkat oleh penguasa (khaliffah), Hal ini sesuai dengan yang dipaparkan oleh Zainudin Al Makbary dalam kitabnya fatḥ al-mu'în, ${ }^{35}$ bahwa, haruslah seorang hakim yang memutus sengketa mendapat penguasaan atau rekomendasi dari seorang imam (pengusa pemerintah) atau lembaga yang mendapat kekuasaan terhadap perhakiman dari pemerintah. Sedangkan hakam adalah belum tentu ditentukan penguasa, Meski dalam kasus tertentu hakam juga di angkat oleh pengusa. ${ }^{36}$ Hakam kebanyakan merupakan pilihan para parties dan atas persetujuanya. Para parties dalam menunjuk hakam berdasarkan kehendak para pihak yang bersengketa.

Kedudukan tạ̧kim adalah lebih rendah dibanding kedudukan pengadilan. Karena hakim memeriksa semua gugatan yang tak dapat dilakukan oleh ḥakam. Lantaran itu Abu Yusuf tidak membolehkan kita mengadakan suatu syarat terhadap taḥkim itu. Selain dari pada itu, hukum yang diberikan oleh hakam hanya berlaku bagi orang-orang yang menerima putusannya, sedang putusan hakim harus berlaku walaupun tidak diterima oleh orang yang bersangkutan. ${ }^{37}$

Dalam ajaran dan tradisi Islam kuno, penyelesaian sengketa yang terjadi di antara pihak yang bersengketa, itu bukan hanya monopoli lembaga pengadilan, karena selain lembaga pengadilan (wilâyat al-qaḍ̂a

\footnotetext{
${ }_{34}$ Muhammad Arifin, Arbitrase Syariah, 233.

35 Abû Bakar al-Shat\}â, H\}âshiyyat I'ânat al-T\}âlibîn 'alâ H\}âli Alfâd Fath\} al-Mu'în, (Bairut:

Darul Fikr, 2002), 241.

36 Ahwan Fanani, 282.

${ }^{37}$ Muhammad Hasbi Ash Shiddieqy, Peradilan Dan Hukum Acara Islam, 81-82.
} 
sebagai lembaga resmi pemerintah, diakui pula lembaga sukarela di luar lembaga formal pengadilan. Lembaga seperti ini sebagai perwujudan lembaga ișâh, yang diprakasai dan dibentuk masyarakat yang memerlukan. $^{38}$

Melihat kualifikasi keahliannya, antara hakam dalam tahkim dan hakim dalam qadâ, keduanya adalah orang yang ahli dalam bidang permasalahan yang diajukan pada keduanya. Ketentuan keahlihan dalam bidangnya dalam fikih klasik adalah seorang hakim haruslah orang yang dapat memiliki sifat adil, dapat melihat, dapat mendengar, menguasai hukum permaslahan yang dihadapkan padanya. ${ }^{39}$ Hal yang tidak jauh berbeda tentang keahlian hakim dan ḥakam adalah penjelasan Mummad Hasbi Ash Shiddiey, ia mengatakan, Ahli fikih menetapkan, bahwa hakam itu hendaknya orang yang mempunyai sifat hakim, yaitu dapat dijadikan saksi baik laki-laki ataupun perempuan, dan benar-benar mempunyai keahlian di waktu ia bertindak sebagai hakam sehingga pada waktu dia menjatuhkan hukum putusanya dianggap adil oleh para parties. ${ }^{40}$

Dan hendaklah sengketa yang di-tahkîm-kan kepadanya adalah sengketa-sengketa yang tidak masuk dalam bidang pidana dan qișâs. Karena dalam bidang ini penguasa yang berkewajiban melaksanakannya, dan karena hukum yang diberikan oleh ḩakam) tidak melibatkan kepada orang-orang lain. Mengingat hal ini, maka tahkim itu dapat dilaksanakan dalam segala hal masalah ijtihadiyah seperti talak, nikah dan jual beli. ${ }^{41}$

Muhammad Hasbi Ashidqieh sebagaimana ia kutip dari Ibnu Qudamah dalam kitab al-mughnî menjelaskan, bahwa hukum yang ditetapkan oleh hakam dalam segala rupa sengketa, terkecuali dalam bidang nikah, li'ân, qadhf dan qisâs. Lebih lanjut ia jelaskan terjadi perbedaan antara ashab Syafi'i dalam masalah yang dapat diselesaikan melalui tahkîm. Ibnu Farhun dalam kitab al-tabshirah mengatakan, bahwa putusan hakam itu berlaku dalam bidang harta atau menentukan keturunan. ${ }^{42}$

Di Indonesia proses tabkim berlaku pada dua hal yakni, hukum yang berkaitan dengan keluarga dan hukum yang barkaitan dengan mu'âmalah. Hal ini dipaparkan oleh Oyo Sunaryo Mukhlas, ia mengatakan bahwa di dalam kesadaran hukum masyarakat dewasa ini, penyelesaian sengketa

\footnotetext{
38 Oyo Sunaryo Mukhlas, Perkembangan Peradilan Islam, 17.

${ }^{39}$ Oyo Sunaryo Mukhlas, Perkembangan Peradilan Islam, 242-243.

40 Muhammad Hasbi Ash Shiddieqy, Peradilan Dan Hukum Acara Islam, 83.

${ }^{41}$ Muhammad Hasbi Ash Shiddieqy, Peradilan Dan Hukum Acara Islam, 83.

42 Muhammad Hasbi Ash Shiddieqy, Peradilan Dan Hukum Acara Islam, 84.
} 
melalui lembaga tạ̣kim itu sudah menjadi model yang jangkauan wewenangnya bukan hanya menyangkut hukum kekeluargaan, tapi juga bidang mu'âmalah. ${ }^{43}$

\section{Kekuatan Putusan melalui Penyelesaian al-Ṣulh.}

Dalam penyelesaian sengketa baik secara litigasi atau non-litigasi, para pihak tentu menunggu putusan dari penyelesaian hakim atau hakam. Telah dijelaskan sebelumnya, bahwa penyelesain sengketa melalui lembaga litigasi sangat mengikat dan memaksa, sehingga para pihak seolah dipaksa untuk mengikuti keputusan hakim. Namun hal yang berbeda pada proses al-sulh (arbitrase), putusan atas sengketa yang diselesaikan di hadapan hakam dalam proses al-sulh (arbitrase) para pihak tidak merasa dipaksa oleh putusan ḩakam, hal ini karena dalam proses alsulh para pihak telah menyepakati hal-hal yang telah dirundingkan sebelumnya.

Apabila cara pendekatan dengan cara kekeluargaan dan perdamaian itu senantiasa ditawarkan dan menjadi model lembaga arbitrase dalam menyelesaikan sengketa, maka tidak akan terlihat adanya kesan salah satu perties menang dan yang satu kalah yang dapat mewariskan karat (sakit) di hati, iri dengki, dendam kesumat, kebencian dan permusuhan di antara mereka. Semua pihak sama-sama menang, karena diputuskan melaui kesepakatan para pihak secara bersama-sama. Dengan demikian putusan lembaga Arbitrase tampak lebih bersahabat dan dapat menentramkan dan menyejukan hati para pihak. ${ }^{44}$

Pada dasarnya, jika para parties memilih menyelesaikan sengketanya melalui proses al-sulb (arbitrase), maka seharusnya para parties tidak diperkenankan menolak keputusan ḅakam (Arbiter). Sayid Sabik mengatakan, ketika proses perdamaian telah selesai, maka kesepakatan yang tertuang dalam akad al-sulb mengikat parties sehingga dalam keadaan seperti ini tidak diperkenankan salah parties membatalkan kesepakatan tanpa adanya keridoan pihak yang lain. ${ }^{45}$

Putusan yang diberikan oleh hakam, harus dilaksanakan oleh orang yang bersangkutan, hal ini sesuai dengan pendapat imam Ahmad, Abu Hanifah dan menurut suatu riwayat dari as Syafi'iyah. Tapi menurut riwayat yang lain, hukum yang diberikan oleh ḥakam tidak harus dituruti oleh yang bersangkutan. Apabila seorang ḅakam telah memberikan

\footnotetext{
43 Oyo Sunaryo Mukhlas, Perkembangan Peradilan Islam, 20.

${ }^{4}$ Oyo Sunaryo Mukhlas, Perkembangan Peradilan Islam, 22.

45 Sayyid Sâbiq, Fiqh al-Sunnah, 210.
} 
putusan, kemudian mereka pergi lagi mengajukan sengketanya kepada ḅakam lain, lalu ḅakam yang lain tersebut memberikan putusan pula dengan tidak mengetahui adanya putusan yang pertama dalam putusannya itu berlawanan dengan putusan yang pertama, maka apabila putusan itu diajukan pada hakim, hendaknya hakim menerapkan hukum yang sesuai pendapatnya. Apabila suatu sengketa sudah diputuskan oleh seorang hakam, kemudian diajukan pada hakim, maka hakim boleh membenarkan putusan hakam itu sesuai dengan madzhabnya. Dan boleh ia membatalkan putusannya itu jika berlawanan dengan madzhabnya. ${ }^{46}$

Di Indonesia proses al-sulh dilakukan oleh Basyarnas dan BANI. Munculnya kedua badan arbitrase tersebut adalah sebagai pembagian wilayah saja, Basyarnas sebagai badan arbitrase yang khusus menangani sengketa keuangan syariah, dan BANI khusus menangani sengketa keuangan dan bisnis konvensioanal. Sengketa yang dapat diselesaikan oleh kedua badan tersebut adalah sengketa yang belum diajukan oleh para parties ke pengadilan. Abdul Manan menjelaskan, ${ }^{47}$ Putusan BAMUI (sekarang Basyarnas) bersifat final dan mengikat parties yang bersengketa, dan wajib bagi parties untuk mentaati putusan tersebut, parties harus segera mentaati dan memenuhi pelaksaanaanya. Apabila ada parties yang tidak melaksanakan secara sukarela, maka putusan itu dijalankan menurut ketentuan yang diatur dalam pasal 637 dan $639 \mathrm{Rv}$, yakni pengadilan negeri memiliki peranan penting dalam memberikan exequatur bagi putusan arbitrase dalam sengketa lembaga keuangan konvensional dan pengadilan agama dalam sengketa di lembaga keungan syari'ah.

Melihat pernyataan ini, terlihat adanya perdebatan tentang hasil putusan al-sulh (arbitrase) baik dalam pandangan ahli hukum Islam ataupun hukum positif di Indonesia. Di lain sisi penyelesaian al-sulh hampir mirip seperti konsiliasi yang tidak mengikat dan menyenangkan hati (arbitrasein equality), dan di sisi yang lain, putusan al-sulb (arbitrase) bersifat final dan mengikat (arbitrasein law).

Menyikapi hal ini sebagaiaman dikutip oleh Muhammad Arifin, Abdel Hamid El Ahdab mengatakan, bahwa sebagian penulis berpandangan, secara syariah arbitration in equlity (emiable compotiton) merupakan ketentuan, sedang arbitration in law merupakan pengecualian, ${ }^{48}$ atau dalam bahasa lain, pada ketentuan awal, arbitrase bertujuan untuk mendamaikan parties

\footnotetext{
46 Muhammad Hasbi Ash Shiddieqy, Peradilan Dan Hukum Acara Islam, 85.

${ }^{47}$ Abdul Manan, Hukum Ekonomi Syariah, 465.

48 Muhammad Arifin, Arbitrase Syariah, 227.
} 
tanpa adanya menang-kalah, hal ini karena putusan dalam arbitrase adalah merupakan kesepakatan parties. Namun karena parties tidak dapat didamaikan melalui cara al-sulḅ (arbitrase) oleh ḥakam atau arbiter, maka jalan terakhir yang harus ditempuh dalam penyelesaian sengketa parties adalah membawa perkera sengketa ke pengadilan, sehingga tidak menyebabkan ketidak adanya kepastian hukum terhadap kepentingan kedua parties. Karena penyelesaian akhir sengketa arbitrase diselesaikan di pengadilan dengan alasan tidak dapat diselesaikan melalui jalur artbitrase setelah melalui proses lama, maka munculah anggapan arbitration in law yang prinsipnya seperti sengketa yang diselesaikan melalui pengadilan.

Dalam kaitan sengketa tidak dapat diselesaikan di depan al-sulb (arbitrase), di Indonesia diatur dalam pasal 59 undanga-undang Nomor 30 Tahun 1999, tentang telah dipenuhinya beberapa syarat, yaitu: (a) dalam waktu paling lama 30 (tiga puluh) hari terhitung sejak tanggal putusan Badan Arbitrase Syariah diucapakan, lembaran asli atau autentik putusan tersebut diserahkan dan didaftarkan oleh Arbiter atau kuasanya kepada panitera pengadilan negeri (pengadilan agama bagi perkara sengketa syariah) yang daerah hukumnya meliputi tempat tinggal termohon dalam penyelesaian sengketa melalui badan arbitrase syariah. (b) Penyerahan dan pendaftaran sebagaimana dimaksud di atas, dilakukan dengan pencatatan dan penanda tanganan pada bagian akhir atau bagian pinggir putusan oleh panitra pengadilan negeri dan Arbiter atau kuasanya yang menyerahkan, dan catatan tersebut merupakan akta pendaftaran. (c) Arbiter atau kuasanya wajib menyerahkan putusan dan lembaran asli pengangkatan sebagai Arbiter atau salinan autentiknya kepada pengadilan negeri. (d) Tidak dipenuhinya ketentuan sebagaimana dimaksud dalam huruf a tersebut, berakibat putusan arbitrase tidak dapat dilaksanakan. Dan (e) semua biaya yang berhubungan dengan pembuatan akta pendaftaran dibebankan pada para pihak. ${ }^{49}$

\section{Kesimpulan}

Al-sulh adalah model pnyelesaian sengketa dalam hukum Islam klasik yang memiliki artian umum. Keumuman arti al-sulh adalah penyelesaian sengketa di luar lembaga pengadilan tanpa menggunakan hakim yang ditugaskan oleh penguasa pemerintah untuk memutus suatu hukum sebagai perlindungan hak rakyat suatu Negara. Al-sulh mencakup

49 Abdul Manan, Hukum Ekonomi Syariah, 469-470. 
perdamaian tanpa wasit dan juga perdamaian dengan menggunakan wasit atau hakam.

Arbitrase dalam hukum Islam dapat disejajarkan dengan konsep tahkim, meskipun istilah tạ̣kim di Indonesia biasanya digunakan dalam sengketa keluarga. Arbitrase dan tạ̣kîm merupakan alternatif penyelesaian sengketa yang dilakukan di luar pengadilan yang membutuhkan Arbiter atau ḥakam sebagai pihak ketiga yang dipilih untuk membantu dalam penyelesaian sengketa para pihak.

Penyelesaian sengketa arbitrase dan tahkim tentu ada perbedaanya. Yakni, pertama, penyelesaian sengketa melalui arbitrase didahului klausul perjanjian yang menyatakan, penyelesaian sengketa diselesaikan jalur arbitrase, walau klausul tersebut tidak menjadi syarat pengajuan penyelesaian sengketa pada badan Arbitrase, sedangkan dalam tạ̧kîm tidak mensyaratkan adanya klausul tersebut. Kedua, jalur arbitrase di Indonesia memiliki obyek tertentu yang dapat disengketakan para pihak, yakni bidang bisnis dan ekonomi atau mu'âmalah, sedang arbitrase Islam sangat identik dengan al-sulh, di mana al-sulb memiliki cakupan obyek yang lebih luas bukan hanya pada bidang bisnis dan ekonomi saja, melainkan obyek hukum yang berkaitan dengan hak-hak manusia dapat diselesaikan dengan al-sulh.

\section{Daftar Pustaka}

Abas, Sihabbudin Abi. Anwâr al-Masâlik. Surabaya: Maktabah Hidayah, t.th.

Abbas, Syahrizal. Mediasi dalam Hukum Syariah, Hukum Adat, dan Hukum Nasional. Jakarta: Kencana Prenada Media Grup, 2011.

Arifin, Muhammad. Arbitrase Syariah sebagai Pilihan Forum Penyelesaian Sengketa Perbangkan Syariah. Yogyakarta: Pustaka Pelajar, 2016. Cet.I.

Basarah, Mochamad. Prosedur Alternatif Penyelesaian Sengketa Arbitrase Tradisional dan Modern (Online). Yogyakarta: Genta Publising, 2011.

Fanani, Ahwan. "Resolusi Konflik Alternatif dalam Hukum Islam" Al Manabij. Vol. VII. No. 2 Juli 2013.

Hidayat, Maskur. Strategi dan Taktik Mediasi, Berdasarkan Perma No.1 Tabun 2016 tentang Prosedur Mediasi Di Pengadilan. Jakarta: Kencana, 2016.

Manan, Abdul. Hukum Ekonomi Syariah dalam Presfektif Kewenangan Pengadilan Agama. Jakarta: Kencana Perdana Media Group, 2014. Cet II. 
Muklhas, Oyo Sunaryo. Perkembangan Pengadilan Islam dari Kabin di Jazirah Arab Kepengadilan Agama di Indonesia. Bogor: Ghalia Indonesia, 2011.

Ridwan. Hukum Ekonomi Syariah di Indonesia. Purwokerto: STAIN Purwokerto Press, 2016.

Rutledge, Pater B. Arbitration and The Constutional. New York: Cambridge University Press, 2014.

Sâbiq, Sayyid. Fiqh al-Sunnah. Sudan: al-Maktabah al-Asyariyah, 2011. Vol. 3.

Setiadi, Tri. "Arbitase Islam dalam Presfektif Islam dan Hukum Positif" Fiat Justisia Jurnal Hukum. Volume 9 No. 3 Juli-September 2015.

Shatâa (al), Abû Bakar. Hâashiyyat I'ânat al-Ṭâlibîn 'alâ Hậli Alfạd Fatḥ alMu'în. Bairut: Darul Fikr, 2002.

Shiddieqy, Muhammad Hasbi Ash-. Pengadilan dan Hukum Acara Islam. Semarang: PT. Pusataka Rizki Putra, 1997. Cet.I.

Sudiarto dan Zaini Asyhadie. Mengenal Arbitase Salab Satu Alternatif Penyelesaian Sengketa Bisnis. Jakarta: PT. Raja Grafindo Persada, 2004.

Sutioso, Bambang. Hukum Arbitase dan Penyelesaian Sengketa. Yogyakarta: Gema Media, 2008.

Undang-undang Republik Indonesia Nomor 30 tahun 1999, Tentang Arbitrasedan Alternatif Penyelesaian sengketa.

Zuhaily, Wahbah. Fiqh al-Islâmi wa Adilatuh. Bairut: Darul Fikr, 2014. Cet. 34. Vol. V. 